\title{
Thianthrene-based oligomers as hole transporting materials
}

\author{
Agnieszka Świst, ${ }^{\text {a Jadwiga Sołoducho, }}{ }^{\text {** Przemysław Data, }},{ }^{\text {b,c }}$ and Mieczysław Lapkowski ${ }^{\text {b,c }}$ \\ ${ }^{a}$ Wrocław University of Technology, Wybrzeże Wyspiańskiego 27, 50-370 Wrocław, Poland \\ ${ }^{b}$ Silesian University of Technology, Department of Chemistry, Strzody 9, 44-100 Gliwice, \\ Poland \\ ${ }^{c}$ Centre of Polymer and Carbon Materials of the Polish Academy of Sciences, Sowińskiego 5, \\ 44-100 Gliwice, Poland \\ E-mail:jadwiga.soloducho@pwr.wroc.pl
}

Dedicated to Professor Rainer Beckert on the occasion of his $60^{\text {th }}$ birthday

\begin{abstract}
The thianthrene-arylene conjugated units have been designed and synthesized via Suzuki or Stille coupling reaction. The structures and properties of the synthesized compounds were characterized by ${ }^{1} \mathrm{HNMR},{ }^{13} \mathrm{CNMR}$, MS, UV-Vis absorption spectroscopy, fluorescence spectroscopy as well as electrochemical measurements. The luminescent studies demonstrate that thianthrenes are good chromophores. Also the electrical properties of obtained films confirm the applicable potential of these novel aryl-based $\pi$-conjugated polymers for the development of various electrical and electrochemical solid-state devices.
\end{abstract}

Keywords: Thianthrene derivatives, Suzuki/Stille condensation, cyclic voltammetry, differential pulse voltammetry (DPV) spectra

\section{Introduction}

Molecular organic materials with conjugated $\pi$-electron systems have found widespread use due to their special optical and electronic properties. Among them, polycyclic aromatic hydrocarbons, such as derivatives of tetracene are frequently applied, for example in organic electronic devices.

In the past, conjugated polymers based on chelating ligands have been prepared, but their solubility is often low. For example, polybipyridinevinylenes, like polybipyridines, are only soluble in formic acid ${ }^{1}$ unless metallated or substituted with solubilizing groups. ${ }^{2}$ Polyfluorenes are known to emit very efficiently under PL or EL conditions with good hole mobility. ${ }^{3,4}$ The large band-gap gives efficient blue emission and potential to transfer its energy to dopant 
emitting molecules with lower band-gaps. The solubilizing groups in poly(9,9-dialkylfluorene) materials lie perpendicular to the conjugated chain, so do not hinder planarity. ${ }^{5}$ Recently, the versatile Suzuki coupling reaction has been utilized to introduce metal binding groups into fluorene alternating copolymers. ${ }^{6}$

Our interest in the design of reversible multi-redox systems contains the synthesis of functionalized thianthrenes. ${ }^{7}$ Thianthrene with $\pi$-donor properties is one of the expected central organic unit for the construction of new type of donor systems with structural and redox properties: a/ oxidation of thianthrene to the $\pi$ radical cation species occurs reversibly, ${ }^{8} b$ / the thianthrene radical cation is thermodynamically stable, $\mathrm{c} /$ thianthrene and oxidized thianthrene units constitute highly ordered arrays with intermolecular interactions involving both $\pi$ - $\pi$ stacking and S-S contact. ${ }^{9}$

Thianthrenes in general have attracted strong interest due to the fascinating physical and chemical properties of numerous sophisticated derivatives. The electron-rich, heterocyclic thianthrene seems to be a good example for charge transporting materials, since it has shown a reversible oxidation behavior at low potential in cyclic voltammetry. ${ }^{10}$

In the present article, we report on the synthesis, spectroscopic and electrochemical properties of new properly functionalized thianthrenes. The properly functionalized thianthrene derivatives (4-7) were assembled from building block 3. The starting compound for obtaining 3 was thianthrene (1), which was lithiated and then unstable compound $\mathbf{2}$ was subsequently boronated into corresponding derivatives $\mathbf{3}$, (Scheme 1). Finally, compound $\mathbf{3}$, under the adapted Suzuki coupling conditions, ${ }^{11,12}$ was converted to the desired thianthrene derivatives 4-7 (Scheme 2a) in moderate yields (around 50\%). Whereas synthesis of compounds 9-13 was based on Stille coupling ${ }^{13}$ between different arylene-derivatives and dibromothianthrene (8) (Scheme 2b). Stannanes were obtained by direct ortho-metalation of suitable arylene groups followed by transmetalation with tributyltin chloride. Dibromothianthrene was synthesized directly from commercially available $\mathbf{1}$ by bromination in acetic acid.

The electrochemical and optical properties of these compounds were measured with attempts made to correlate to their respective $\pi$-electron conjugation lengths as well as their molecular conformations. The most efficient optical materials seem to be the ones with various electron-donor (D) and electron-acceptor (A) moieties attached symmetrically to a conjugate linker.

The chemical structures of 3-13 were confirmed by ${ }^{1} \mathrm{H}$ and ${ }^{13} \mathrm{C}$ NMR as well as MS and UV spectroscopy for selected compounds.

\section{Results and Discussion}

\section{Synthesis}

We have designed a group of monomers containing a thianthrene entity and elaborated short routes for their synthesis (Schemes 1,2). 


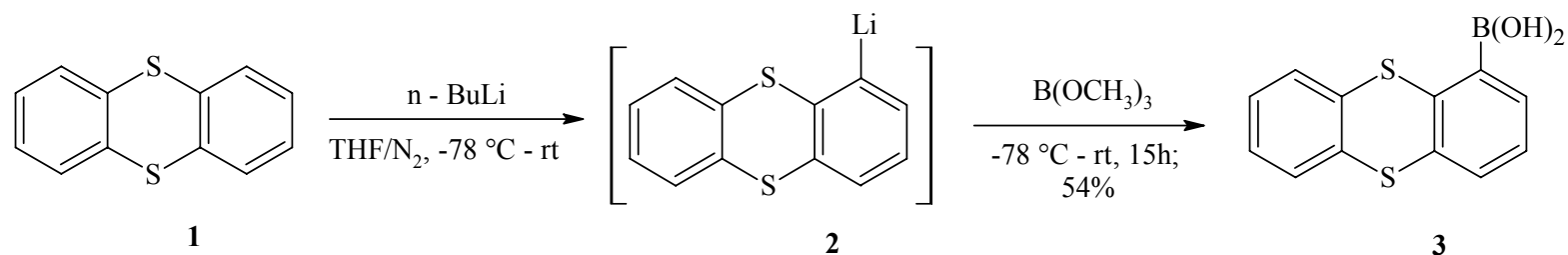

\section{Scheme 1}

The synthesis of a few molecules (4-7), was established by the use of metal catalyzed crosscoupling reactions as follows (Scheme 2a). The reaction of thianthrene in tetrahydrofuran with tert-butyllithium at $-78^{\circ} \mathrm{C}$ produced unstable 1-lithiothianthrene (2), then with trimethyl borate thianthren-1-yl boronic acid (3). The cross-coupling reaction of thianthren-1-yl boronic acid with dibromoalkyl derivatives of fluorene-, carbazole-, diphenylamine-, phenothiazine in the presence of catalytic amounts of $\mathrm{Pd}\left(\mathrm{PPh}_{3}\right)_{4}$ in a two-phases system (toluene/2 $\mathrm{M} \mathrm{K}_{2} \mathrm{CO}_{3}$ in volume ratio 2:1) at $90^{\circ} \mathrm{C}$ gave 4-7 in around $50 \%$ isolated yields, respectively.

All the synthesized compounds except $\mathbf{6 c}$ were isolated after the synthesis as oily products.

Molecules 9-13 were synthesized by the use of palladium catalyzed Stille-coupling reactions as follows (Scheme 2b). Starting from dibromothianthrene (8), ${ }^{14}$ which was condensed with appropriate tributyltin derivative of thiophene, 3,4-ethylenedioxythiophene, furan, oxazole and pyridine, the products $\mathbf{9 - 1 3}$ were obtained. ${ }^{15}$ The cross coupling reactions were performed in toluene under reflux conditions in the presence of palladium catalyst $\left(\mathrm{Pd}\left(\mathrm{PPh}_{3}\right)_{4}\right),($ Scheme $2 \mathrm{~b})$.

\section{Electrochemical properties}

Electrochemical investigation of the compounds in dichloromethane has shown that all molecules undergo multi-electron oxidation processes but the initial potentials depend on the molecular structure and were found as $0.93 \mathrm{~V}$ for $\mathbf{6 a}, 1.10 \mathrm{~V}$ for $\mathbf{5 b}, 1.21 \mathrm{~V}$ for $\mathbf{4 a}$, and $1.25 \mathrm{~V}$ for 7c, respectively as shown in Figure 1 and Table 1. The first oxidation peak of compounds occurs at $1.16 \mathrm{~V} \mathrm{6a}, 1.47 \mathrm{~V} \mathrm{7c}, 1.50 \mathrm{~V} \mathrm{5b}, 1.51 \mathrm{~V}$ 4a. Oxidation of all monomers was reversible in the low oxidation potential region (up to first oxidation peak) (Figure 1 insets). When the oxidation potential is much higher than the first oxidation wave, the next peaks are less reversible and probably products of degradation may occur on the electrode. During the successive scans, there are no significant changes in the voltammograms, and lack of growing current suggested absence of an electropolymerization process in the solution as well.

Thianthrene monomer with diphenylamine core (6a) has the lowest oxidation potential equal to $1.16 \mathrm{~V}$, and is responsible for oxidation of diphenylamine unit. Oxidation potential near 1.40 $\mathrm{V}$ in all investigated compounds is responsible for oxidation of thianthrene group. Differential pulse voltammetry (DPV) spectra (Figure 2) exibit that oxidation potential peaks are similar for all thianthrene derivatives. Redox processes in the potential range of $1.4 \mathrm{~V}-1.75 \mathrm{~V}$ concerns the first and second oxidation step of thianthrene group. In respect to that, the peak of $\mathbf{6 a}$ located at 
potential $1.10 \mathrm{~V}$ is due to the presence of the diphenylamine unit, when carbazole $7 \mathbf{c}$ and fluorene $\mathbf{5 b}$ group have similar redox peaks at a potential near $1.6 \mathrm{~V}$. The phenothiazine $4 \mathbf{a}$ unit has an oxidation potential around $1.75 \mathrm{~V}$ because of irregular shape of oxidation peak.

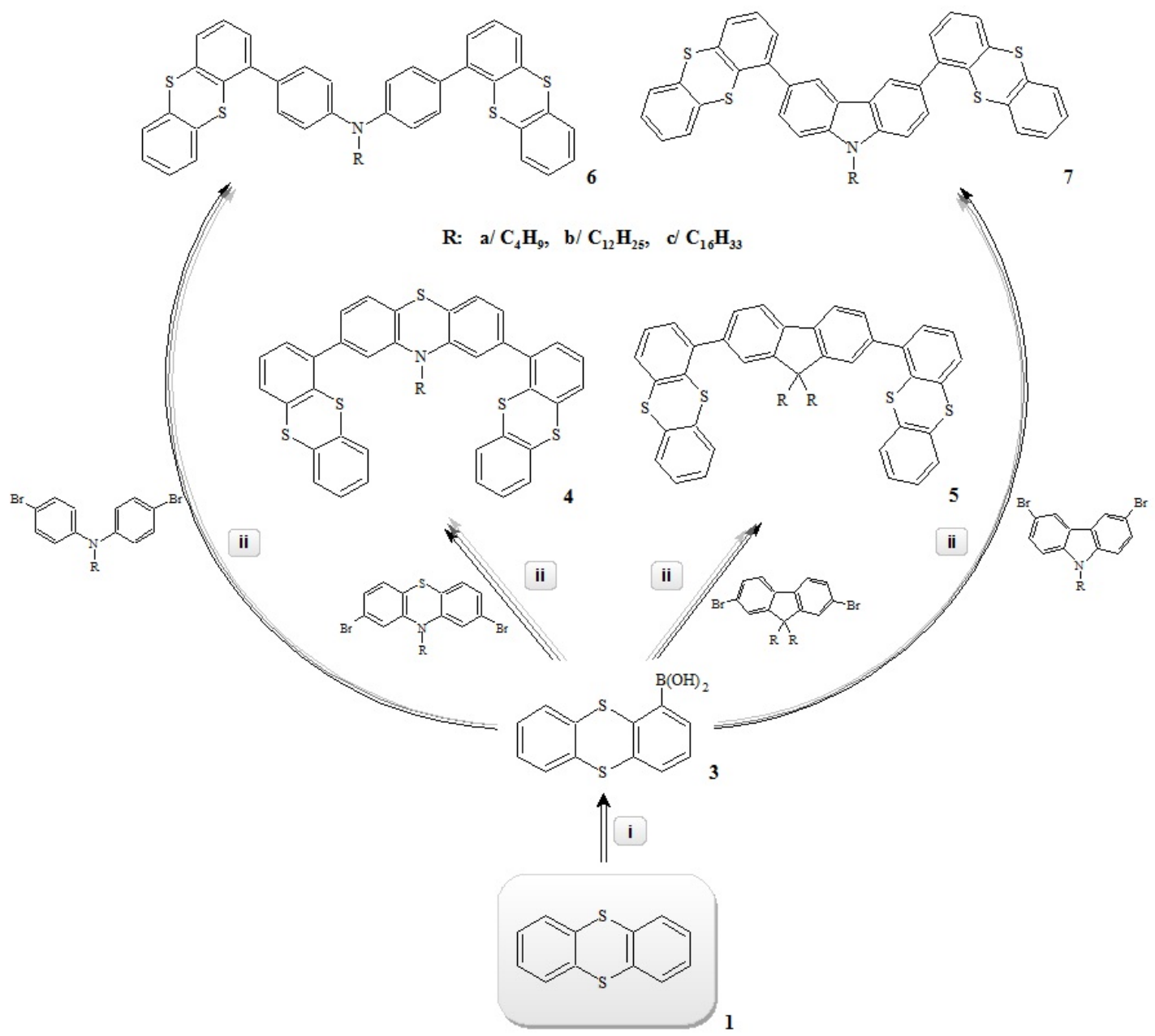

Scheme 2a. Synthesis of bis(thianthrene) derivatives. Conditions of reactions: (i) BuLi, $\mathrm{B}\left(\mathrm{OCH}_{3}\right)_{3}, \mathrm{THF},-78^{\circ} \mathrm{C}-\mathrm{rt}, \mathrm{N}_{2}, 16 \mathrm{~h}$, (ii) $\mathrm{Pd}\left(\mathrm{PPh}_{3}\right)_{4}, 2 \mathrm{M} \mathrm{K}_{2} \mathrm{CO}_{3 \text { aq }}$, toluene, $\mathrm{N}_{2}, 90^{\circ} \mathrm{C}, 24 \mathrm{~h}$. 


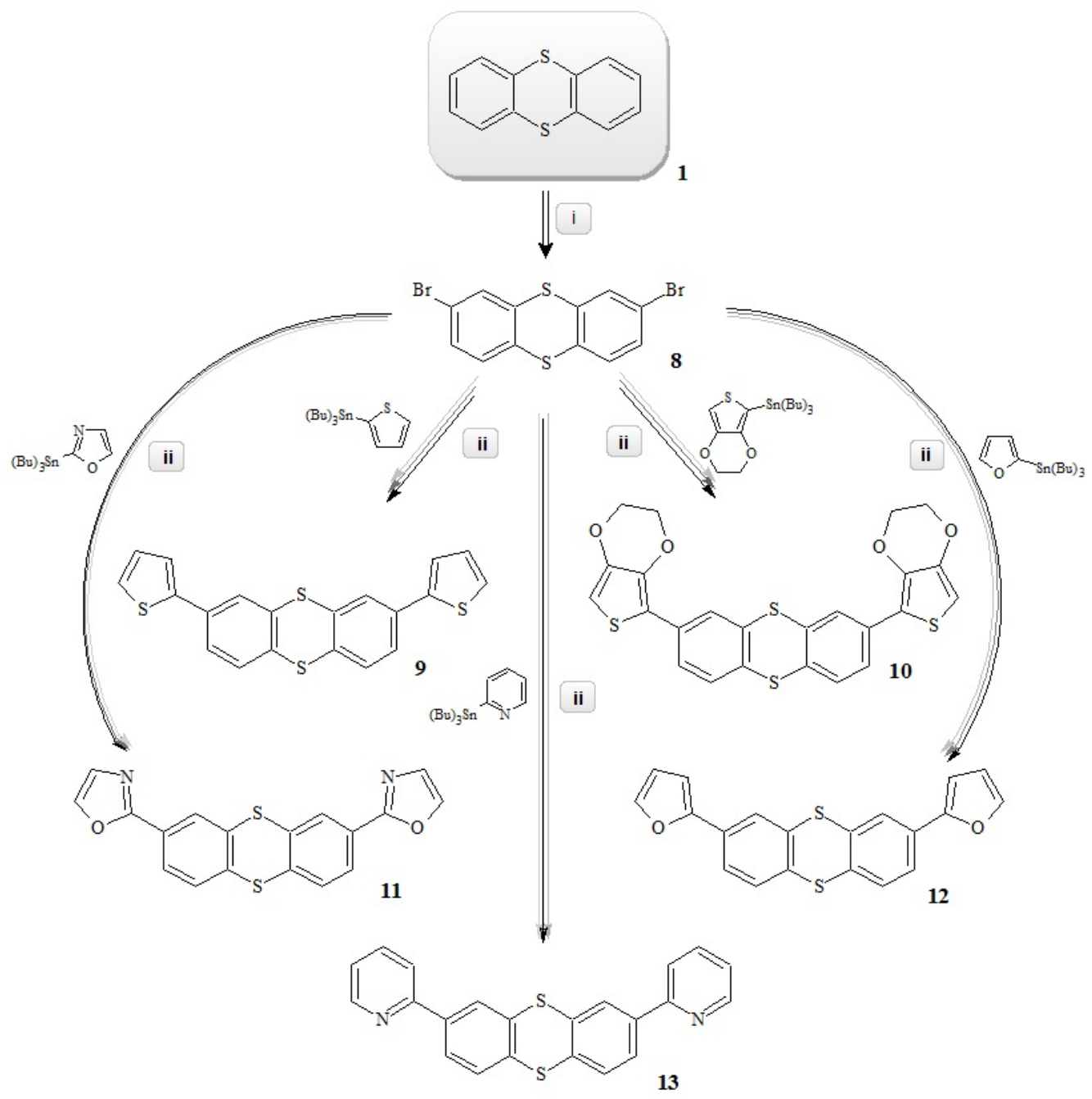

Scheme 2b. Synthesis of di(aryl)thianthrenes. Conditions of reactions: (i) $\mathrm{Br}_{2}, \mathrm{CH}_{3} \mathrm{COOH}$, reflux, 16h, (ii) $\mathrm{Pd}\left(\mathrm{PPh}_{3}\right)_{4}$, toluene, $\mathrm{N}_{2}, 90^{\circ} \mathrm{C}, 24 \mathrm{~h}$. 

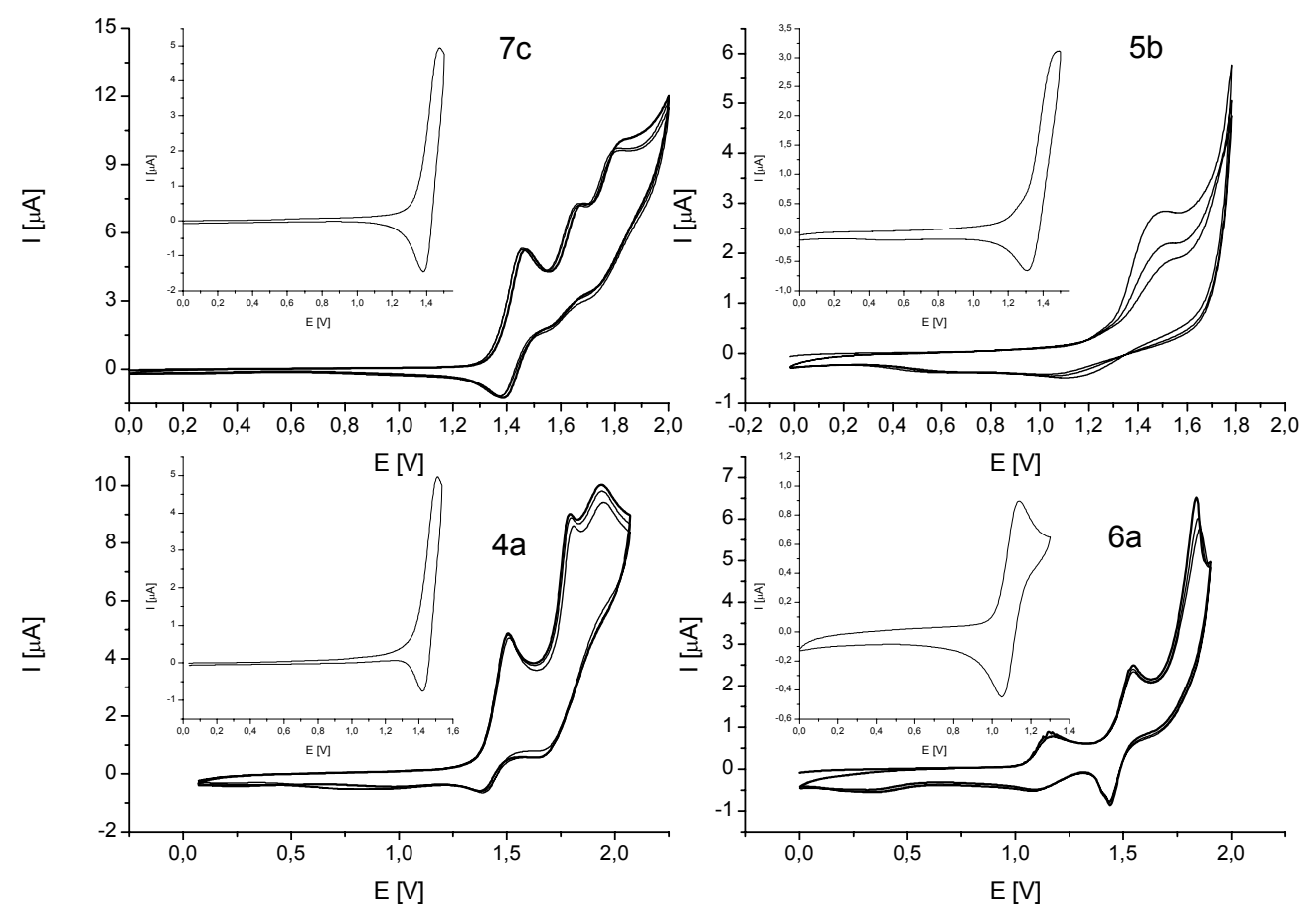

Figure 1. Cyclic voltammetry of investigated monomers; scan rate $50 \mathrm{mV} / \mathrm{s}, \mathrm{Ag} / \mathrm{AgCl}$ reference electrode.
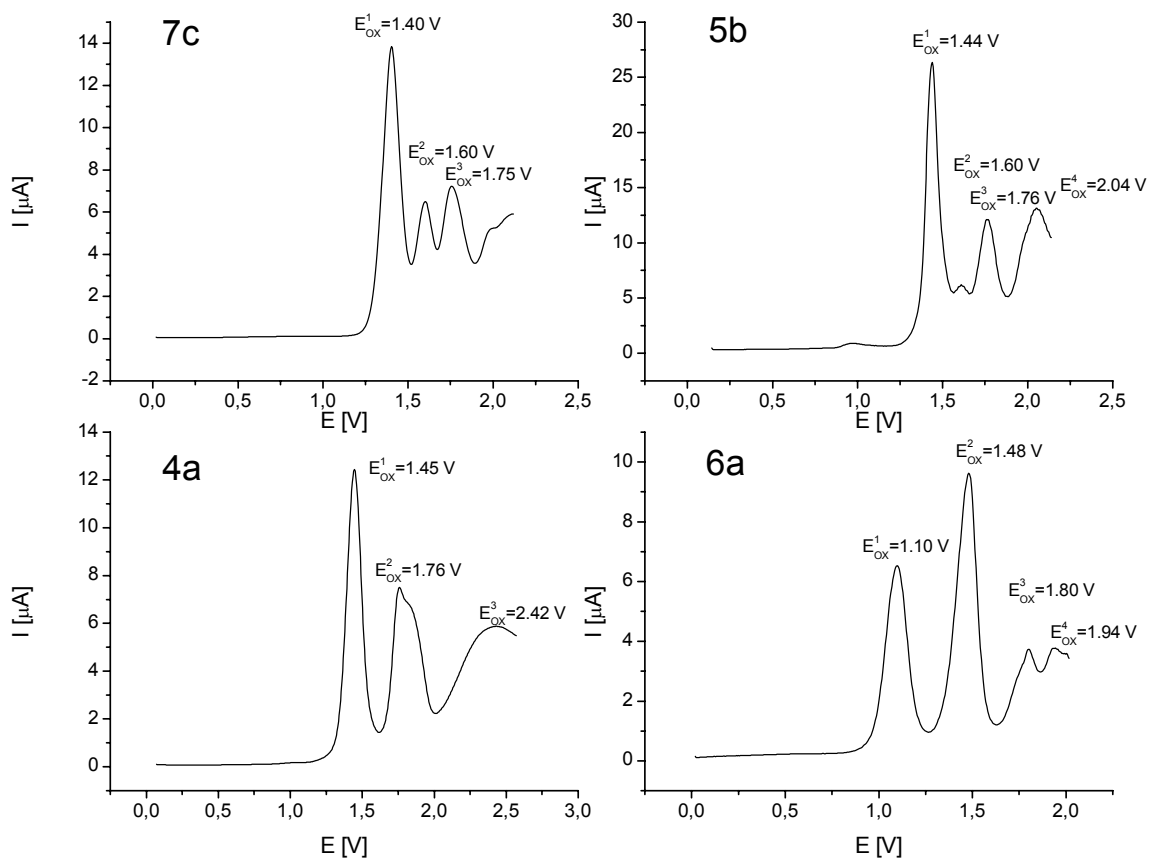

Figure 2. DPV spectra of investigated monomers; scan rate $50 \mathrm{mV} / \mathrm{s}, \mathrm{Ag} / \mathrm{AgCl}$ - reference electrode. 
DPV spectra (Figure 2) show absolute peaks of oxidation and reduction processes. In correlation to the molecular band, the oxidation peak is related to the HOMO band and the reduction peak is related to the LUMO band. The electrochemical band-gap value is the range between those peaks (Table 1).

Table 1. Electrochemical band-gap and oxidation potential data

\begin{tabular}{c|ccccc}
\hline Compounds & $5 \mathrm{~b}$ & $7 \mathrm{a}$ & $7 \mathrm{c}$ & $6 \mathrm{a}$ & $4 \mathrm{a}$ \\
\hline $\begin{array}{c}\mathrm{E}_{\mathrm{G}}{ }^{\text {elec }}[\mathrm{eV}] \\
\begin{array}{c}\text { Initial oxidation } \\
\text { potential [V] }\end{array}\end{array}$ & 2.62 & 3.92 & 3.95 & 2.80 & 3.45 \\
$\begin{array}{c}\text { First oxidation } \\
\text { potential [V] }\end{array}$ & 1.50 & 1.47 & 1.25 & 0.93 & 1.21 \\
\hline
\end{tabular}

Comparing 7a and 7c where there is only difference in alkyl chain (Figure 3), we observe only small deviation between oxidation peaks. From a practical point of view, compound 7c has a longer alkyl chain and has much better solubility. From electrochemical point of view, it is clear that 7c is more stable in redox process than 7a. In CV's of 7a we found lowering current in next cycle what suggests that the electrode surface is blocked.

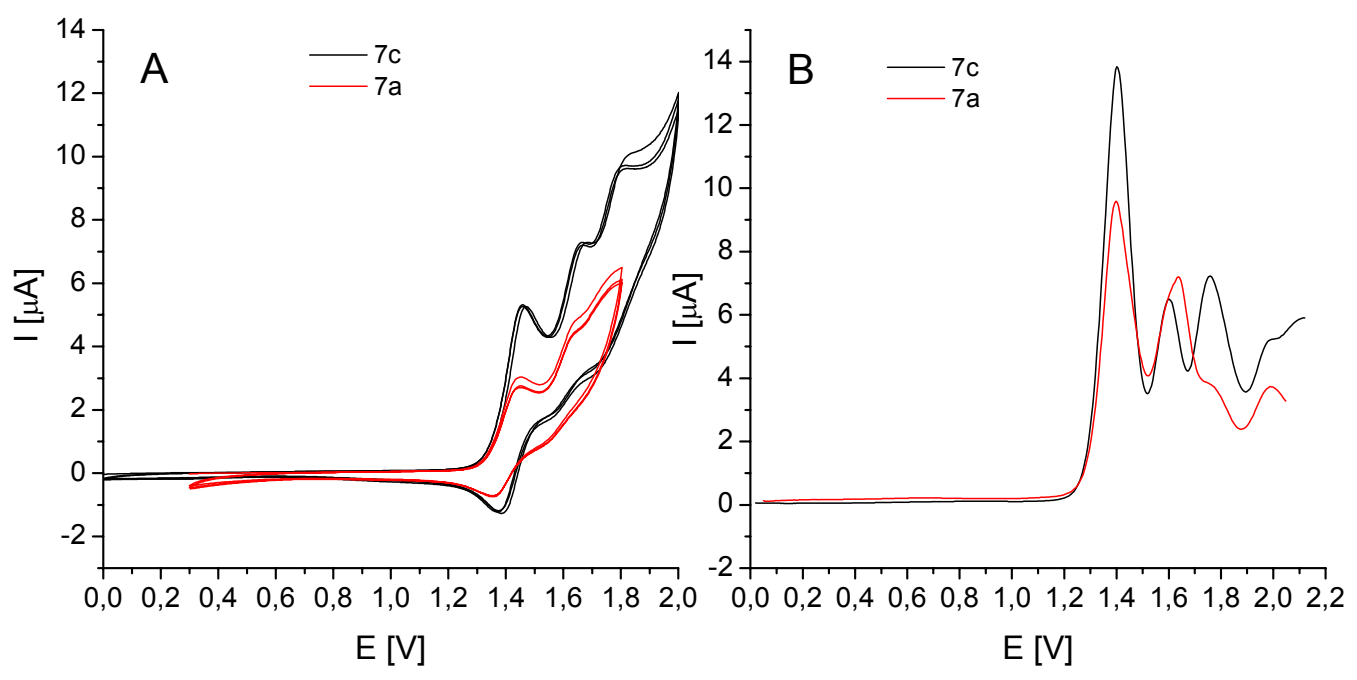

Figure 3. Comparison of a) cyclic voltammetry data and b) DPV of thianthrene-carbazole derivatives with different alkyl chains; scan rate $50 \mathrm{mV} / \mathrm{s}, \mathrm{Ag} / \mathrm{AgCl}$ - reference electrode.

\section{Optical properties of thianthrene derivatives. Absorption and luminescence characteristic}

The photophysical characteristics of thianthrene derivatives (6a, 4a) were investigated by ultraviolet-visible (UV-Vis) absorption and photoluminescence (PL) in dilute dichloromethane 
solution $\left(4 \times 10^{-6} \mathrm{~mol} / \mathrm{L}\right)$. The optical data are also summarized in Table 2. A plot of extinction coefficient versus wavelength is depicted in Figure 4.

The one-photon absorption (OPA) spectra of $6 \mathbf{a}$ and $4 \mathbf{a}$ consist of three bands; in case of $\mathbf{6 a}$ one high-intensity, high-energy band at $260 \mathrm{~nm}$ and a low-energy $352 \mathrm{~nm}$. It was clear that the absorption bands of 4a appeared at 231 (high-energy) nm, $263 \mathrm{~nm}$ and 318 (low-energy) nm. For 6a, the absorption bands red-shifted compared with $\mathbf{4 a}$, the bands were located at 260, 320, 352 $\mathrm{nm}$. Except that, much larger extinction coefficient of the absorption bands of $\mathbf{6 a}$ rather than those 4a were obtained (Table 2). The OPA spectrum of $\mathbf{4 a}$ is little different from those of $\mathbf{6 a}$. Such differences may be caused by a stronger donor core used as the $\pi$-bridge in the chromophore 6a.
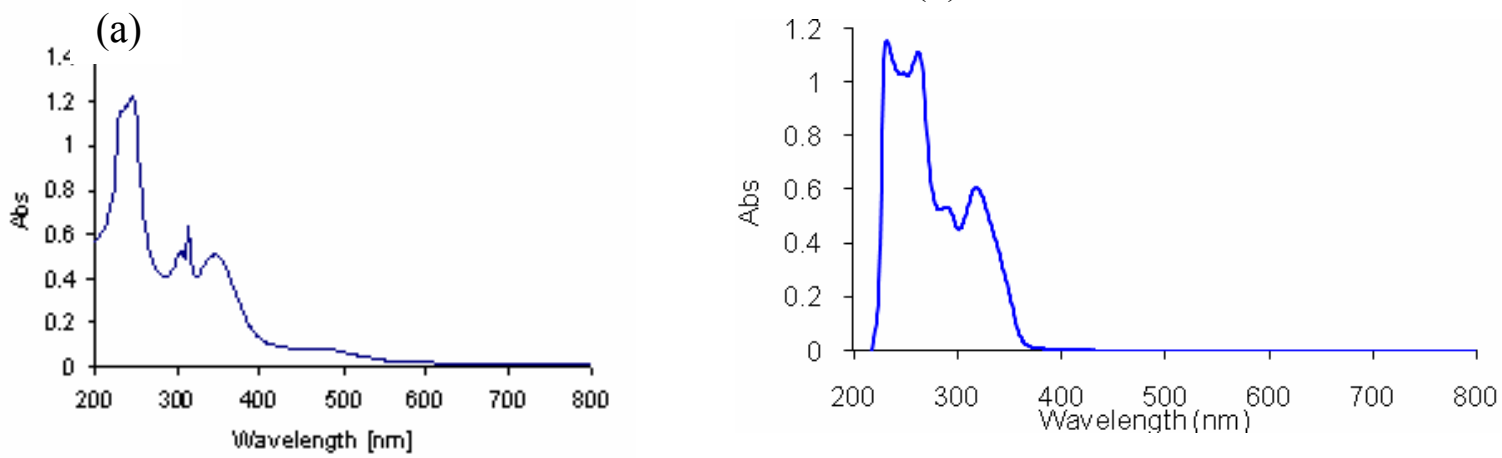

Figure 4. UV-Vis absorption spectra of $6 \mathbf{a}(\mathrm{a})$ and $4 \mathbf{a}(\mathrm{b})$ in dichloromethane $\left(4 \times 10^{-6} \mathrm{~mol} / \mathrm{L}\right)$.

Table 2. Photophysical data of $6 \mathbf{a}$ and $4 \mathbf{a}$

\begin{tabular}{c|cccc}
\hline \multirow{2}{*}{ Compound } & \multicolumn{4}{|c}{ In dichloromethane solution } \\
\cline { 2 - 5 } & $\begin{array}{c}\text { abs } \lambda_{\max }^{\mathrm{a}} \\
{[\mathrm{nm}]}\end{array}$ & $\varepsilon^{\mathrm{a}} \times 10^{-4}$ & $\begin{array}{c}\lambda_{\max }^{\mathrm{b}} \\
{[\mathrm{nm}]}\end{array}$ & $\varphi_{\mathrm{f}}$ \\
\hline $\mathrm{a}$ & 260,352 & $\begin{array}{c}1.72, \\
0.78\end{array}$ & 452 & 0.22 \\
\hline $\mathrm{4a}$ & 241,318 & $\begin{array}{c}1.68, \\
0.96\end{array}$ & 504 & 0.39 \\
\hline
\end{tabular}

${ }^{\mathrm{a}}$ One-photon absorption maxima (nm) and coefficients ( $\varepsilon$ was in unit of $\left.\mathrm{dm}^{3} \mathrm{~mol}^{-1} \mathrm{~cm}^{-1}\right) .{ }^{\mathrm{b}}$ Onephoton emission fluorescence maxima $(\mathrm{nm})$.

The one-photon excited fluorescence (OPEF) spectra of $\mathbf{6 a}$ and $\mathbf{4 a}$ were similar, which both feature an intense luminescence at $452-504 \mathrm{~nm}$ with a shoulder at $384-412 \mathrm{~nm}$. As shown in Figure 5 and Table 2, both chromophores emit in the blue region, and the emission maximum exhibits a 52-nm red shift from 6a to 4a. The observed red shift is probably because of enlarging of the conjugation in case of $\mathbf{4 a}$. The fluorescent quantum yield was measured with quinine 
sulfate as the standard (Table 2), and it increased from $6 \mathbf{a}$ to $4 \mathbf{a}$. The $\varphi_{\mathrm{f}}$ of $\mathbf{4 a}$ was very close to phenothiazine-based polymers. ${ }^{16}$
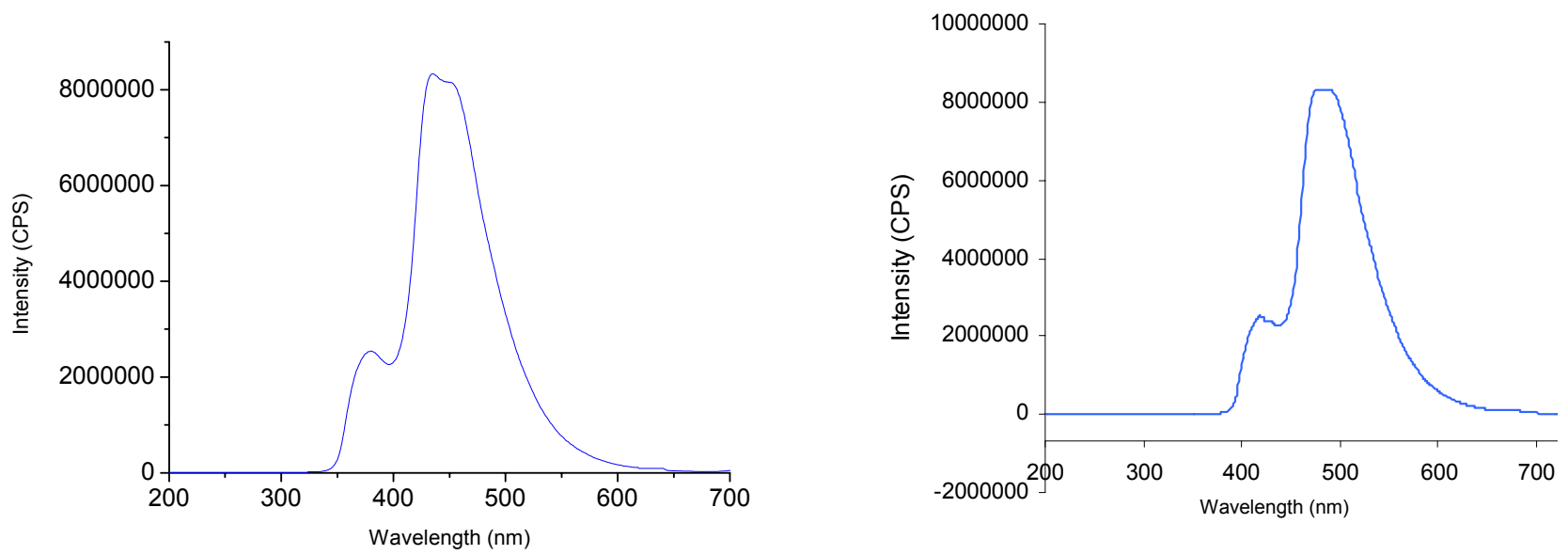

Figure 5. Fluorescence emission spectra of $6 \mathbf{a}(\mathrm{a})$ and $4 \mathbf{a}(\mathrm{b})$ in dichloromethane $\left(4 \times 10^{-6} \mathrm{~mol} / \mathrm{L}\right)$.

The di(aryl)thianthrenes are interesting because of their blue emission properties as well as bis(thianthrene)derivatives. The diluted solutions of obtained derivatives (9, 10, 12) have maximum of emission in the region $450-481 \mathrm{~nm}$ (Figure 6).

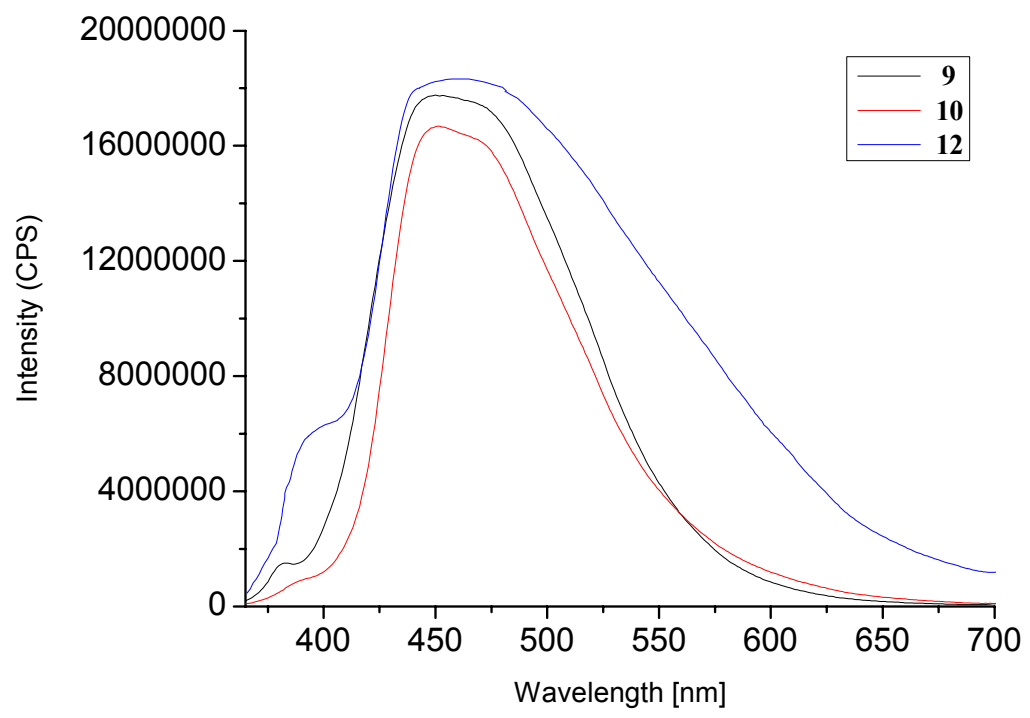

Figure 6. Fluorescence emission spectra of 9, 10, 12 in dichloromethane $\left(4 \times 10^{-6} \mathrm{~mol} / \mathrm{L}\right)$. 


\section{X-Ray structure determination of bis(thiophene)thianthrene}

The structure of single molecule of $\mathbf{9}$ is depicted in Figure 7 together with the numbering system adopted. The molecule possesses the following stereochemically characteristic features.

a/ The fused thianthrene and thiophene rings are almost butterfly-like structures because the thianthrene derivatives are folded along the S-S axis.

b/ The thiophene rings are twisted out of the plane of the thianthrene by the dihedral angle of 14.2-20.3 $3^{\circ}$.

Interestingly, molecules of 9 , have a geometry with no $\mathrm{S} \cdots \mathrm{S}$ contacts, where the sulfur atoms of thiophenes are far from each other. The molecular long axis of $\mathbf{9}$ is perpendicular to the $a b$ plane in the unit cell. The crystal of 9 showed no $\mathrm{S}^{\cdots} \mathrm{S}$ intermolecular interactions.

We were pleased to find that the crystal growing method yielded a single-crystal structure of 9 stabilized through hydrogen bonding. Crystallographic analysis found the crystal system as orthorhombic with space group $P 2{ }_{1} 2_{1} 2_{1}$. The unit-cell dimensions and other X-ray data are shown in Table 3. From the crystallographic analysis is clear that most of molecules of compound 9 are presented as displayed in Figure 7a.

Since the torsion angles between the thianthrene and two thiophene rings are not large enough to disconnect the $\pi$-conjugation through the three rings, the $\pi$-electron system apparently denotes the UV absorptions and, therefore, the fluorescence.
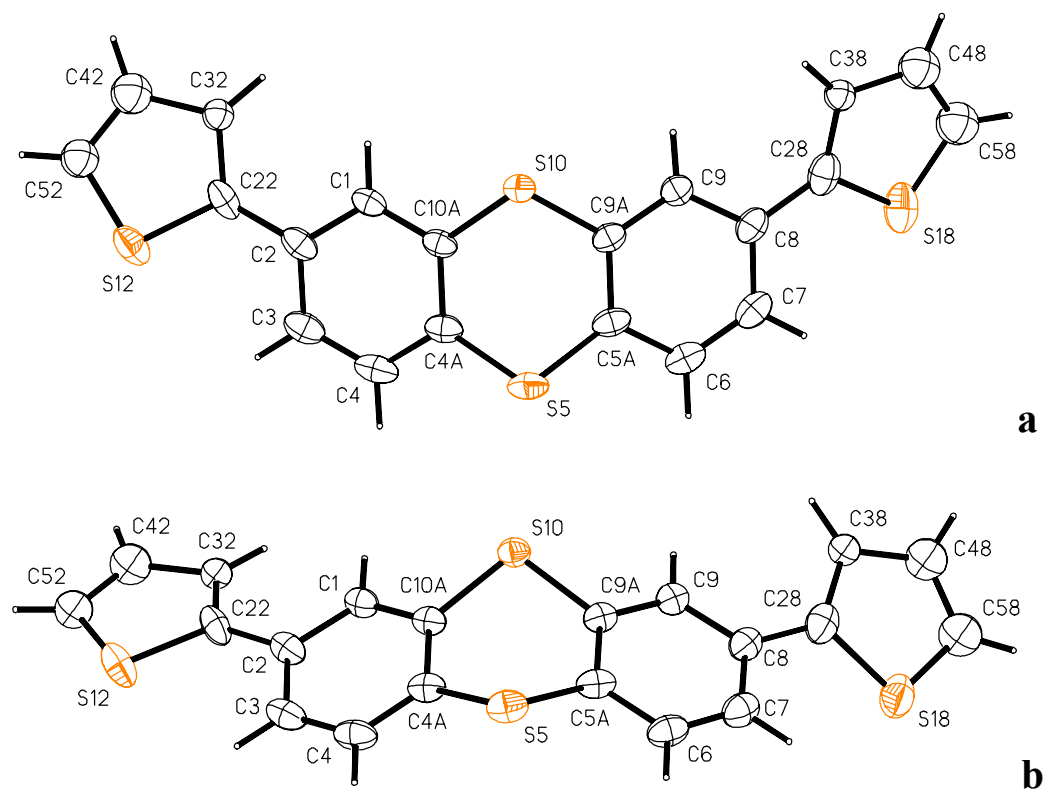

Figure 7. Crystallographic structure of compound 9 in two projections (number for each atom): a/ generally occurred; selected bond lengths $(\AA)$ and angles $\left({ }^{\circ}\right)$ : C(58)-C(48), 1354 (2); C(48)$\mathrm{C}(38), 1.439$ (2); C(38)-C(28), 1.379 (2); C(58)-S(18), 1.711 (2); C(22)-C(2), 1.483 (4); S(10)$\mathrm{C}(10), 1.710$ (2); C(10)-S(10)-C(9), 103.33 (9); C(4)-S(5)-C(5), 103.25 (10); C(9)-C(8)-C(28), 121.15 (2); b/ example of other rarely occurred conformations 
Table 3. Selected crystallographic data of compound 9

\begin{tabular}{c|c}
\hline Empirical formula & $\mathrm{C}_{20} \mathrm{H}_{12} \mathrm{~S}_{4}$ \\
\hline $\mathrm{Fw}\left(\mathrm{g} \mathrm{mol}^{-1}\right)$ & 380.54 \\
Crystal system & orthorhombic \\
Space group & $P 2_{1} 2_{1} 2_{1}$ \\
$a(\AA)$ & $6.017(2)$ \\
$b(\AA)$ & $16.387(4)$ \\
$c(\AA)$ & $17.218(4)$ \\
$V\left(\AA^{3}\right)$ & $1697.7(8)$ \\
$Z$ & 4 \\
$T(\mathrm{~K})$ & $100(2)$ \\
& $\mathrm{C}(58)-\mathrm{C}(48), 1354(2)$ \\
& $\mathrm{C}(48)-\mathrm{C}(38), 1.439(2)$ \\
Selected Bond & $\mathrm{C}(38)-\mathrm{C}(28), 1.379(2)$ \\
lengths $(\AA)$ and bond & $\mathrm{C}(58)-\mathrm{S}(18), 1.711(2)$ \\
angles $\left({ }^{\circ}\right)$ & $\mathrm{C}(22)-\mathrm{C}(2), 1.483(4)$ \\
& $\mathrm{S}(10)-\mathrm{C}(10), 1.710(2)$ \\
& $\mathrm{C}(10)-\mathrm{S}(10)-\mathrm{C}(9), 103.33(9)$ \\
& $\mathrm{C}(4)-\mathrm{S}(5)-\mathrm{C}(5), 103.25(10)$ \\
& $\mathrm{C}(9)-\mathrm{C}(8)-\mathrm{C}(28), 121.15(2)$ \\
\hline
\end{tabular}

\section{Conclusions}

New derivatives of thianthrene containing different arylene cores were synthesized according to Suzuki or Stille condensation and their optical, electrochemical properties were studied (Figure 8). The lowest energy absorption edges and the lowest ionization potentials were observed for diphenylamine thianthrene derivatives.

The obtained semiconducting units as viable luminance and high hole-transporting one, exhibit good solubility in common organic solvents, thermal stability and luminescence in blue region and can be cast into uniform films. They possess good fluorescence quantum. The band gap values of synthesized compounds are in the adequate range $(2.62-3.95 \mathrm{eV})$ for testing as semiconductors.

In the investigation of functional organic electroluminescent materials, the relationship between the organic molecular structure and the optoelectronic property should be always established. Now, the investigation of the organic molecular structure and the optoelectronic function is still at the stage of registering data. 
Among the three basic colors, blue, red and green, for full color display, while the efficiency, color purity and life-time of the former two have met the requirements of commercialization, the blue light is still lagging behind. Therefore, we succeeded in establishing a new type of organic hybrid molecules with blue luminescence.

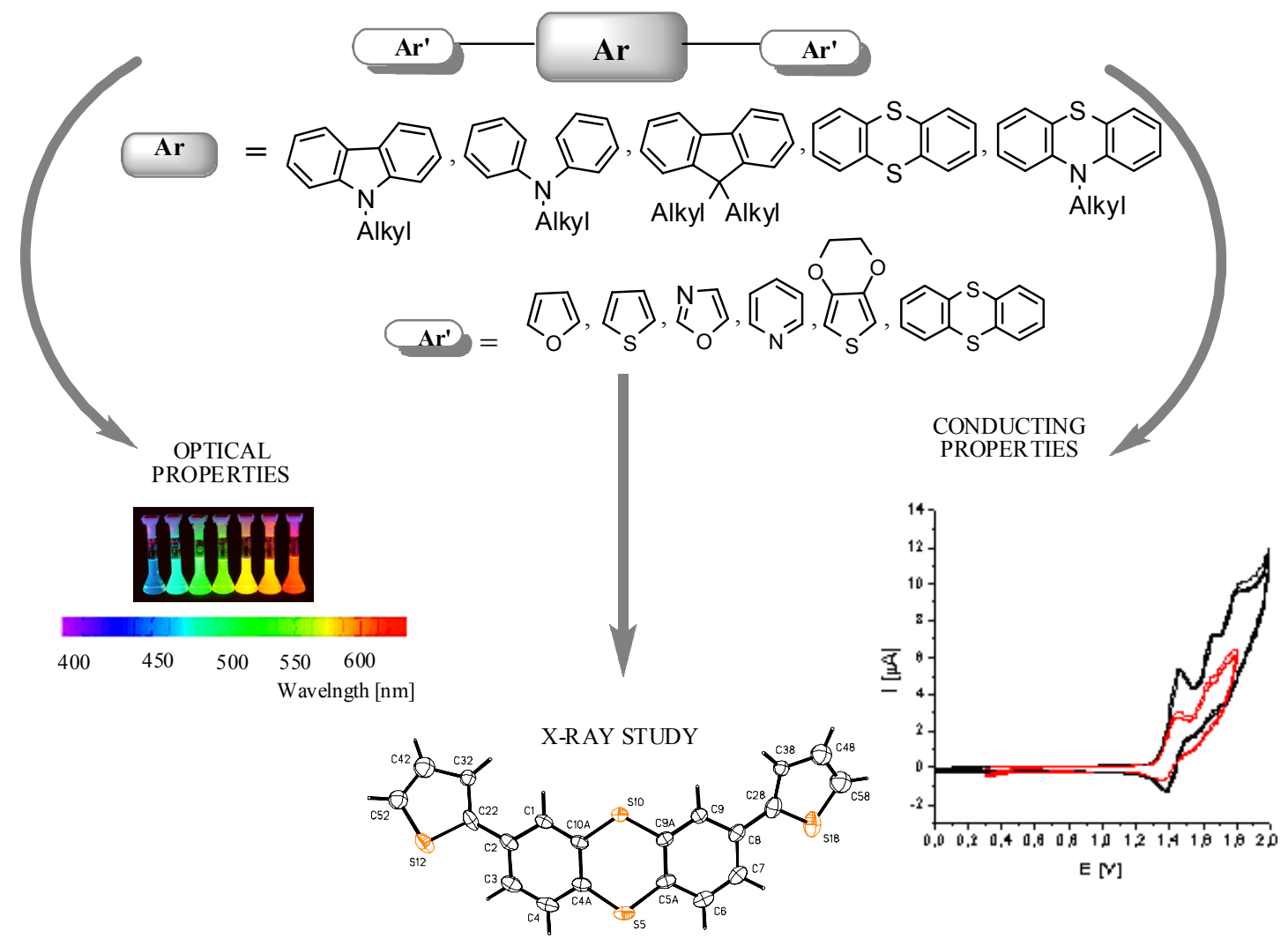

Figure 8. General pathway of synthesis and application of thianthrenes.

Further studies will be aimed at mapping the precise relationship between the doping level and the electrochemical properties of the polymers.

\section{Experimental Section}

General. All chemicals, reagents and solvents were used as received from commercial sources without further purification, except toluene and tetrahydrofuran (THF), which was distilled over sodium/benzophenone. ${ }^{1} \mathrm{H} \mathrm{NMR}$ and ${ }^{13} \mathrm{C} \mathrm{NMR}$ spectra were recorded in $\mathrm{CDCl}_{3}$ and DMSO on a Brücker 300 spectrometer. Chemical shifts are denoted in $\delta$ unit (ppm) and were referenced to internal tetramethylsilane $(0.0 \mathrm{ppm})$. The splitting patterns are designated as follows: $\mathrm{s}$ (singlet), $\mathrm{d}$ (doublet), dd (doublet of doublets), $\mathrm{t}$ (triplet), quin (quintet), and m (multiplet). Mass spectra were recorded on a Waters GCT Premier spectrometer operating at an ionization potential of 70 
$\mathrm{eV}$ and on a LCT Premier XE with ESI+ ionization. Preparative column chromatography was carried out on glass columns of different sizes packed with silica gel Merck 60 (0.035-0.070 $\mathrm{mm}$ ). Absorption spectra were gathered with UV-Vis HP 8452A diode array spectrophotometer. Fluorescence spectra were collected with a Hitachi F-2500 fluorescence spectrophotometer.

Thianthren-1-ylboronic acid (3). According to the procedure ${ }^{17}$, to a stirred suspension of thianthrene $(2.0 \mathrm{~g}, 9.25 \mathrm{mmol})$ in anhydrous tetrahydrofuran $(40 \mathrm{ml})$ at $-78^{\circ} \mathrm{C}$ under an atmosphere of nitrogen was added very slowly, dropwise $2.5 \mathrm{M}$ in hexane tert-butyllithium (1.3 $\mathrm{ml}, 13.6 \mathrm{mmol})$. After addition was complete the mixture was allowed to warm to ambient temperature. The resulting red solution was stirred for around $30 \mathrm{~min}$ before being re-cooled to $-78^{\circ} \mathrm{C}$ for the slow addition of trimethyl borate $(98 \%, 6.2 \mathrm{ml}, 55.5 \mathrm{mmol})$. After 15 hours at room temperature aqueous hydrochloric acid $(3 \mathrm{M}, 25 \mathrm{ml})$ was added and crude product was extracted by diethyl ether. The ethereal phase was washed with water and brine, dried over magnesium sulfate and the solvent evaporated leaving a white oil which was crystallized from benzene to obtain clean product as a white powder. Yield 54\%, $1.30 \mathrm{~g}, \mathrm{mp} 147-148^{\circ} \mathrm{C} .{ }^{1} \mathrm{H}$ NMR (DMSO$\left.\mathrm{d}_{6}\right): \delta_{\mathrm{H}} 7.26-7.36\left(4 \mathrm{H}_{\text {arom }}, \mathrm{m}, 4 \mathrm{CH}\right), 7.51-7.56\left(3 \mathrm{H}_{\text {arom }}, \mathrm{m}, 3 \mathrm{CH}\right), 8.40\left(2 \mathrm{H}, \mathrm{d}, J=1.1 \mathrm{~Hz}, \mathrm{~B}(\mathrm{OH})_{2}\right)$. ${ }^{13} \mathrm{C}$ NMR (DMSO-d 6 ): $\delta_{\mathrm{C}} 127.5,128.5,128.5,128.8,129.0,129.3,129.4,132.1,133.9,135.4$, 136.0, 138.3.

\section{General procedure for preparation of compounds 4-7}

2,7-bis(1-thianthrene)-9,9-didodecylfluorene (5b). The following general Suzuki procedure was used for the preparation all of the bis(thianthren-1-yl) derivatives. To a three-necked flask was added thianthren-1-yl boronic acid (1.73 g, $6.67 \mathrm{mmol})$, 9,9-didodecyl-2,7-dibromofluorene $(2.00 \mathrm{~g}, 3.04 \mathrm{mmol})$, and a mixture of anhydrous toluene $(35 \mathrm{ml})$ and $2 \mathrm{M}$ aqueous potassium carbonate solution $(21 \mathrm{ml})$. The flask equipped with a condenser was then evacuated and filled with nitrogen several times to remove traces of the air. $\mathrm{Pd}\left(\mathrm{PPh}_{3}\right)_{4}(0.45 \mathrm{~g}, 0.39 \mathrm{mmol})$ was then added under nitrogen atmosphere. The mixture was heated at $90^{\circ} \mathrm{C}$ for $24 \mathrm{~h}$ under nitrogen. The separated aqueous layer was extracted with chloroform $(3 \times 15 \mathrm{ml})$. The organic phase was washed thrice with water $(15 \mathrm{ml})$. The combined organic layers were dried over anhydrous magnesium sulfate, and the solvent was removed by rotary evaporation. The crude product was purified by silica gel column chromatography with hexane:ethyl acetate $(8: 1, \mathrm{~V} / \mathrm{V})$ as eluent. Product (colourless oil) was obtained with yield 47\% (1.33 g). ${ }^{1} \mathrm{H}$ NMR $\left(\mathrm{CDCl}_{3}\right): \delta_{\mathrm{H}} 0.85(6 \mathrm{H}, \mathrm{t}$, $\left.J=6.8 \mathrm{~Hz}, 2 \mathrm{CH}_{3}\right), 1.05-1.26\left(40 \mathrm{H}, \mathrm{m}, 20 \mathrm{CH}_{2}\right), 2.05-2.11\left(4 \mathrm{H}, \mathrm{m}, 2 \mathrm{CH}_{2}\right), 7.14-7.27\left(4 \mathrm{H}_{\text {arom. }}, \mathrm{m}\right.$, $4 \mathrm{CH}), 7.29-7.33\left(2 \mathrm{H}_{\text {arom. }}\right.$ dd, $\left.J=1.4 \mathrm{~Hz}, J=7.5 \mathrm{~Hz}, 2 \mathrm{CH}\right), 7.33\left(2 \mathrm{H}_{\text {arom. }}, \mathrm{d}, J=7.5 \mathrm{~Hz}, 2 \mathrm{CH}\right), 7.37$ $\left(2 \mathrm{H}_{\text {arom. }}, \mathrm{d}, J=1.3 \mathrm{~Hz}, 2 \mathrm{CH}\right), 7.39\left(2 \mathrm{H}_{\text {arom. }}, \mathrm{d}, J=7.7 \mathrm{~Hz}, 2 \mathrm{CH}\right), 7.46\left(2 \mathrm{H}_{\text {arom. }}, \mathrm{d}, J=1.2 \mathrm{~Hz}, 2 \mathrm{CH}\right)$, 7.50-7.56 $\left(4 \mathrm{H}_{\text {arom. }}, \mathrm{m}, 4 \mathrm{CH}\right), 7.85\left(2 \mathrm{H}_{\mathrm{arom}}, \mathrm{d}, J=7.7 \mathrm{~Hz}, 2 \mathrm{CH}\right) .{ }^{13} \mathrm{C} \mathrm{NMR}\left(\mathrm{CDCl}_{3}\right): \delta_{\mathrm{C}} 14.0$ $\left(2 \mathrm{CH}_{3}\right), 22.6\left(2 \mathrm{CH}_{2}\right), 24.1\left(2 \mathrm{CH}_{2}\right), 29.2\left(2 \mathrm{CH}_{2}\right), 29.5\left(2 \mathrm{CH}_{2}\right), 29.6\left(4 \mathrm{CH}_{2}\right), 29.7\left(2 \mathrm{CH}_{2}\right), 30.2$ $\left(2 \mathrm{CH}_{2}\right), 31.8\left(2 \mathrm{CH}_{2}\right), 40.5\left(2 \mathrm{CH}_{2}\right), 55.3\left(2 \mathrm{CH}_{2}\right), 119.6,124.4,127.0,127.5,127.7,128.0,128.1$, $128.5,128.7,129.1,135.3,135.3,136.1,136.5,139.0,140.4,143.0,150.9$ (C-Ar). Anal. Calcd for $\mathrm{C}_{61} \mathrm{H}_{70} \mathrm{~S}_{4}: \mathrm{C}, 78.66 ; \mathrm{H}, 7.57$; $\mathrm{S}, 13.77 \%$, Found: C, 78.56; H, 7.59; S, 13.67\% 
3,6-Bis(thianthren-1-yl)- $\boldsymbol{N}$-butylcarbazole (7a). The compound was prepared by the above general Suzuki procedure for 2,7-bis(thianthren-1-yl)-9,9-didodecyl-fluorene. The quantities of substrates were as follows: thianthren-1-yl boronic acid $(0.63 \mathrm{~g}, 2.40 \mathrm{mmol}), 2,8$-dibromo- $N$ butylcarbazole $(0.60 \mathrm{~g}, 1.09 \mathrm{mmol}), \mathrm{Pd}\left(\mathrm{PPh}_{3}\right)_{4}(0.02 \mathrm{~g}, 0.01 \mathrm{mmol})$. The crude product was purified by silica gel column chromatography with hexane:ethyl acetate $(9: 1, \mathrm{~V} / \mathrm{V})$ as eluent. Ivory oily product was synthesized with $48 \%$ yield $(0.50 \mathrm{~g}) .{ }^{1} \mathrm{H} \mathrm{NMR}\left(\mathrm{CDCl}_{3}\right): \delta_{\mathrm{H}} 1.06(3 \mathrm{H}, \mathrm{t}$, $\left.J=7.4 \mathrm{~Hz}, \mathrm{CH}_{3}\right), 1.50-1.62\left(2 \mathrm{H}, \mathrm{m}, \mathrm{CH}_{2}\right), 1.96-2.06\left(2 \mathrm{H}, \mathrm{m}, \mathrm{CH}_{2}\right), 4.43(2 \mathrm{H}, \mathrm{t}, J=7.2 \mathrm{~Hz}, \mathrm{~N}-$ $\left.\mathrm{CH}_{2}\right), 7.11-7.40\left(10 \mathrm{H}_{\text {arom. }}, \mathrm{m}, 10 \mathrm{CH}\right), 7.49-7.56\left(8 \mathrm{H}_{\text {arom. }}, \mathrm{m}, 8 \mathrm{CH}\right), 8.15\left(2 \mathrm{H}_{\text {arom. }}, \mathrm{s}, 2 \mathrm{C}-\mathrm{CH}-\mathrm{C}\right.$, carbazole). ${ }^{13} \mathrm{C}$ NMR $\left(\mathrm{CDCl}_{3}\right): \delta_{\mathrm{C}} 14.1\left(\mathrm{CH}_{3}\right), 20.8\left(\mathrm{CH}_{2}\right), 31.4\left(\mathrm{CH}_{2}\right), 43.3\left(\mathrm{~N}_{-} \mathrm{CH}_{2}\right), 108.5$, $121.4,122.8,127.1,127.5,127.6,127.7,127.9$, 128.5, 128.9, 129.8, 131.3, 135.1, 135.5, 136.3, 136.5, 140.6, 143.3 (C-Ar). MS, $m / z(\%)=651.12$; Anal. Calcd for $\mathrm{C}_{40} \mathrm{H}_{29} \mathrm{NS}_{4}$ : C, 73.69; $\mathrm{H}$, 4.48 ; N, 2.15; S, 19.67\%, Found: C, 73.70; H, 4.46; N, 2.14; S, 19.57\%

3,6-Bis(thianthren-1-yl)- $\boldsymbol{N}$-hexadecylcarbazole (7c). Ivory oil, yield $44 \%, 0.39$ g. ${ }^{1} \mathrm{H}$ NMR $\left(\mathrm{CDCl}_{3}\right): \delta_{\mathrm{H}} 0.88\left(3 \mathrm{H}, \mathrm{t}, J=6.5 \mathrm{~Hz}, \mathrm{CH}_{3}\right), 1.12-1.45\left(26 \mathrm{H}, \mathrm{m}, 13 \mathrm{CH}_{2}\right), 1.92-2.06\left(2 \mathrm{H}, \mathrm{m}, \mathrm{CH}_{2}\right)$, $4.40\left(2 \mathrm{H}, \mathrm{t}, J=7.0 \mathrm{~Hz}, \mathrm{CH}_{2}\right), 7.09-7.38\left(10 \mathrm{H}_{\text {arom. }}, \mathrm{m}, 10 \mathrm{CH}\right), 7.46-7.59\left(8 \mathrm{H}_{\text {arom. }}, \mathrm{m}, 8 \mathrm{CH}\right), 8.12$ $\left(2 \mathrm{H}_{\text {arom., }}\right.$ s, $2 \mathrm{C}-\mathrm{CH}-\mathrm{C}$, carbazole). ${ }^{13} \mathrm{C} \mathrm{NMR}\left(\mathrm{CDCl}_{3}\right): \delta_{\mathrm{C}} 14.2\left(\mathrm{CH}_{3}\right), 22.8\left(\mathrm{CH}_{2}\right), 27.5\left(\mathrm{CH}_{2}\right)$, $29.1\left(\mathrm{CH}_{2}\right), 29.3\left(\mathrm{CH}_{2}\right), 29.4\left(2 \mathrm{CH}_{2}\right), 29.6\left(2 \mathrm{CH}_{2}\right), 29.8\left(5 \mathrm{CH}_{2}\right), 32.0\left(\mathrm{CH}_{2}\right), 43.6\left(\mathrm{~N}-\mathrm{CH}_{2}\right)$, $108.4,121.4,122.8,127.0,127.3,127.8,128.0,128.5,128.9,129.4,129.8,131.3,135.1,135.5$, 136.3, 136.5, 140.5, 143.3 (C-Ar). MS, $m / z(\%)=819.31$; Anal. Calcd for $\mathrm{C}_{52} \mathrm{H}_{53} \mathrm{NS}_{4}$ : C, 76.14; H, 6.51; N, 1.71; S, 15.64\%, Found: C, 76.10; H, 6.57; N, 1.66; S, 15.60\%

4,4'-Bis(thianthren-1-yl)- $\mathbf{N}$-butyldiphenylamine (6a). Green oil, yield 48\%, $0.82 \mathrm{~g} .{ }^{1} \mathrm{H} \mathrm{NMR}$ $\left(\mathrm{CDCl}_{3}\right): \delta_{\mathrm{H}} 1.02\left(3 \mathrm{H}, \mathrm{t}, J=7.3 \mathrm{~Hz}, \mathrm{CH}_{3}\right) 1.42-1.54\left(2 \mathrm{H}, \mathrm{m}, \mathrm{CH}_{2}\right), 1.77-1.90\left(2 \mathrm{H}, \mathrm{m}, \mathrm{CH}_{2}\right), 3.87$ $\left(2 \mathrm{H}, \mathrm{t}, J=7.7 \mathrm{~Hz}, \mathrm{~N}-\mathrm{CH}_{2}\right), 7.16-7.32\left(12 \mathrm{H}_{\text {arom. }}, \mathrm{m}, 12 \mathrm{CH}\right), 7.38\left(4 \mathrm{H}_{\text {arom. }}, \mathrm{d}, J=6.8 \mathrm{~Hz}, 4 \mathrm{CH}\right)$, 7.43-7.46 (2H arom., dd, $J=1.4 \mathrm{~Hz}, J=7.3 \mathrm{~Hz}, 2 \mathrm{CH}), 7.49-7.52\left(4 \mathrm{H}_{\text {arom. }}\right.$, dd, $J=2.0 \mathrm{~Hz}, J=7.0 \mathrm{~Hz}$, $4 \mathrm{CH}) .{ }^{13} \mathrm{C}$ NMR $\left(\mathrm{CDCl}_{3}\right): \delta_{\mathrm{C}} 14.2\left(\mathrm{CH}_{3}\right), 20.5\left(\mathrm{CH}_{2}\right), 28.9\left(\mathrm{CH}_{2}\right), 52.4\left(\mathrm{~N}_{-} \mathrm{CH}_{2}\right), 120.4,127.2$, 127.6, 127.8, 128.0, 128.6, 129.0, 129.5, 130.6, 133.0, 135.1, 135.3, 136.3, 136.6, 142.4, 147.4 (C-Ar). MS, $m / z(\%)=653.13$; Anal. Calcd for $\mathrm{C}_{40} \mathrm{H}_{31} \mathrm{NS}_{4}: \mathrm{C}, 73.47 ; \mathrm{H}, 4.78 ; \mathrm{N}, 2.14 ; \mathrm{S}$, 19.61\%, Found: C, 73.50; H, 4.76; N, 2.10; S, 19.56\%

4,4'-Bis(thianthren-1-yl)- $N$-hexadecyl-diphenylamine (6c). Beige crystals, yield 51\%, $0.76 \mathrm{~g}$, mp 76-78 ${ }^{\circ}$. ${ }^{1} \mathrm{H} \mathrm{NMR}\left(\mathrm{CDCl}_{3}\right): \delta_{\mathrm{H}} 1.02\left(3 \mathrm{H}, \mathrm{t}, J=7.3 \mathrm{~Hz}, \mathrm{CH}_{3}\right), 1.42-1.54\left(26 \mathrm{H}, \mathrm{m}, 13 \mathrm{CH}_{2}\right)$, 1.77-1.90 (2H, m, $\left.\mathrm{CH}_{2}\right), 3.85\left(2 \mathrm{H}, \mathrm{t}, J=7.7 \mathrm{~Hz}, \mathrm{~N}-\mathrm{CH}_{2}\right), 7.17-7.32\left(12 \mathrm{H}_{\text {arom. }}, \mathrm{m}, 12 \mathrm{CH}\right), 7.38$ ( $\left.4 \mathrm{H}_{\text {arom. }}, \mathrm{d}, J=6.8 \mathrm{~Hz}, 4 \mathrm{CH}\right), 7.43-7.46\left(2 \mathrm{H}_{\text {arom. }}\right.$, dd, $\left.J=1.4 \mathrm{~Hz}, J=7.3 \mathrm{~Hz}, 2 \mathrm{CH}\right), 7.49-7.52$ $\left(4 \mathrm{H}_{\text {arom. }}, \mathrm{dd}, J=2.0 \mathrm{~Hz}, J=7.0 \mathrm{~Hz}, 4 \mathrm{CH}\right) .{ }^{13} \mathrm{C} \mathrm{NMR}\left(\mathrm{CDCl}_{3}\right): \delta_{\mathrm{C}} 14.2\left(\mathrm{CH}_{3}\right), 22.8\left(\mathrm{CH}_{2}\right), 27.2$ $\left(\mathrm{CH}_{2}\right), 27.7\left(\mathrm{CH}_{2}\right), 29.4\left(\mathrm{CH}_{2}\right), 29.6\left(\mathrm{CH}_{2}\right), 29.7\left(3 \mathrm{CH}_{2}\right), 29.8\left(5 \mathrm{CH}_{2}\right), 32.0\left(\mathrm{CH}_{2}\right), 52.6\left(\mathrm{~N}-\mathrm{CH}_{2}\right)$, $120.3,127.1,127.5,127.8,128.0,128.5,129.0,129.4,130.5,133.0,135.0,135.2,136.2,136.5$, 142.4, 147.4 (C-Ar). MS, $m / z(\%)=821.33$; Anal. Calcd for $\mathrm{C}_{52} \mathrm{H}_{55} \mathrm{NS}_{4}$ : C, 75.96; H, 6.74; N, 1.70; S, 15.60\%, Found: C, 75.97; H, 6.71; N, 1.66; S, 15.63\%

2,8-bis(thianthren-1-yl)- $N$-butylphenothiazine (4a). The compound was prepared by the above general Suzuki procedure for 2,7-bis(1-thianthrene)-9,9-didodecyl-fluorene. The quantities of substrates were as follows: 1-thianthreneboronic acid (1.30 g, $5.00 \mathrm{mmol})$, 2,8-dibromo- $N$-butyl- 
phenothiazine $(0.9 \mathrm{~g}, 2.18 \mathrm{mmol}), \mathrm{Pd}\left(\mathrm{PPh}_{3}\right)_{4}(0.34 \mathrm{~g}, 0.29 \mathrm{mmol})$. The method of purification of crude product - silica gel column chromatography with hexane:ethyl acetate $(7: 1 ; \mathrm{V} / \mathrm{V})$ as an eluent. Product (pinkish oil) was obtained with $49 \%$ yield $(0.76 \mathrm{~g}) .{ }^{1} \mathrm{H} \mathrm{NMR}\left(\mathrm{CDCl}_{3}\right): \delta_{\mathrm{H}} 1.12$ $\left(3 \mathrm{H}, \mathrm{t}, J=7.3 \mathrm{~Hz}, \mathrm{CH}_{3}\right), 1.58-1.66\left(2 \mathrm{H}, \mathrm{m}, \mathrm{CH}_{2}\right), 2.03-2.10\left(2 \mathrm{H}, \mathrm{m}, \mathrm{CH}_{2}\right), 4.32(2 \mathrm{H}, \mathrm{t}, J=7.8 \mathrm{~Hz}$, N-CH 2$), 7.20-7.32\left(8 \mathrm{H}_{\text {arom. }}, \mathrm{m}, 8 \mathrm{CH}\right), 7.40-7.43\left(2 \mathrm{H}_{\text {arom. }}, \mathrm{dd}, J=1.4 \mathrm{~Hz}, J=7.4 \mathrm{~Hz}, 2 \mathrm{CH}\right), 7.49-$ $7.58\left(6 \mathrm{H}_{\text {arom. }}, \mathrm{m}, 6 \mathrm{CH}\right), 7.73-7.77\left(2 \mathrm{H}_{\text {arom. }}, \mathrm{dd}, J=2.1 \mathrm{~Hz}, J=8.8 \mathrm{~Hz}, 2 \mathrm{CH}\right), 8.22\left(2 \mathrm{H}_{\text {arom. }}\right.$ d, $J=2.1 \mathrm{~Hz}, 2 \mathrm{CH}) \cdot{ }^{13} \mathrm{C} \mathrm{NMR}\left(\mathrm{CDCl}_{3}\right): \delta_{\mathrm{C}} 13.9\left(\mathrm{CH}_{3}\right), 20.2\left(\mathrm{CH}_{2}\right), 29.0\left(\mathrm{CH}_{2}\right), 48.6\left(\mathrm{~N}-\mathrm{CH}_{2}\right)$, $115.7,124.1,124.4,127.5,127.8,128.0,128.6,128.8,129.1,129.4,134.1,134.6,135.0,135.5$, 136.2, 136.3, 140.2 (C-Ar). MS, $m / z(\%)=727.15$; Anal. Calcd for $\mathrm{C}_{40} \mathrm{H}_{29} \mathrm{NS}_{5}$ : C, 70.24; $\mathrm{H}$, 4.27 ; N, 2.05; S, 23.44\%, Found: C, 70.21; H, 4.24; N, 2.10; S, 23.40\%

2,8-Bis(thianthren-1-yl)- $N$-hexadecylphenothiazine (4c). Orange oil, yield $40 \%, 0.88 \mathrm{~g} .{ }^{1} \mathrm{H}$ $\operatorname{NMR}\left(\mathrm{CDCl}_{3}\right): \delta_{\mathrm{H}} 0.86\left(3 \mathrm{H}, \mathrm{t}, J=6.5 \mathrm{~Hz}, \mathrm{CH}_{3}\right), 1.13-1.44\left(26 \mathrm{H}, \mathrm{m}, 13 \mathrm{CH}_{2}\right), 2.05-2.12(2 \mathrm{H}, \mathrm{m}$, $\left.\mathrm{CH}_{2}\right), 4.30\left(2 \mathrm{H}, \mathrm{t}, J=7.9 \mathrm{~Hz}, \mathrm{~N}-\mathrm{CH}_{2}\right), 7.18-7.33\left(8 \mathrm{H}_{\text {arom. }}, \mathrm{m}, 8 \mathrm{CH}\right), 7.41-7.44$ ( $2 \mathrm{H}_{\text {arom. }}, \mathrm{dd}, J=1.7$ $\mathrm{Hz}, J=7.4 \mathrm{~Hz}, 2 \mathrm{CH}), 7.48-7.58\left(6 \mathrm{H}_{\text {arom. }}, \mathrm{m}, 6 \mathrm{CH}\right), 7.73-7.77\left(2 \mathrm{H}_{\text {arom. }}\right.$, dd, $J=2.2 \mathrm{~Hz}, J=8.8 \mathrm{~Hz}$, $2 \mathrm{CH}), 8.22\left(2 \mathrm{H}_{\text {arom. }}, \mathrm{d}, J=2.2 \mathrm{~Hz}, 2 \mathrm{CH}\right) .{ }^{13} \mathrm{C} \mathrm{NMR}\left(\mathrm{CDCl}_{3}\right): \delta_{\mathrm{C}} 14.2\left(\mathrm{CH}_{3}\right), 22.7\left(\mathrm{CH}_{2}\right), 26.9$ $\left(\mathrm{CH}_{2}\right), 29.4\left(\mathrm{CH}_{2}\right), 29.4\left(\mathrm{CH}_{2}\right), 29.5\left(\mathrm{CH}_{2}\right), 29.6\left(5 \mathrm{CH}_{2}\right), 29.7\left(2 \mathrm{CH}_{2}\right), 30.1\left(\mathrm{CH}_{2}\right), 32.0\left(\mathrm{CH}_{2}\right)$, $48.9\left({\left.\mathrm{~N}-\mathrm{CH}_{2}\right)}_{2}, 115.7,124.0,124.4,127.5,127.8,128.0,128.6,128.8,129.1,129.3,134.1,134.6\right.$, 135.0, 135.5, 136.2, 136.3, 140.2, 140.2 (C-Ar). MS, $m / z(\%)=851.28$; Anal. Calcd for $\mathrm{C}_{52} \mathrm{H}_{53} \mathrm{NS}_{5}$ : C, 73.28; H, 6.27; N, 1.64; S, 18.81\%, Found: C, 73.25; H, 6.22; N, 1.66; S, 18.78\%

\section{General procedure for preparation of compounds 9-13}

2,8-Bis(2-thiophene)thianthrene (9). The following general Stille coupling procedure was used for the preparation of all the thianthrene derivatives. To the dibromothianthrene $(1.0 \mathrm{~g}, 2.67$ mmol) in anhydrous toluene $(50 \mathrm{ml})$ stirred under nitrogen, was added 2(tributylstannyl)thiophene $(2.2 \mathrm{~g}, 5.90 \mathrm{mmol})$, then $\mathrm{Pd}\left(\mathrm{PPh}_{3}\right)_{4}(0.50 \mathrm{~g}, 0.43 \mathrm{mmol})$. The mixture was heated in reflux for $24 \mathrm{~h}$ and yellow-green solution was obtained. The reaction was then quenched by water $(30 \mathrm{ml})$ and extracted with chloroform. The resulting organic solution was dried over anhydrous $\mathrm{MgSO}_{4}$ and the solvent was removed. The residue was purified by silica gel column chromatography with hexane as an eluent. Product (9) was obtained with yield 61\% $(0.62 \mathrm{~g})$ as a pale green solid, $\mathrm{mp} 176-179^{\circ} \mathrm{C} .{ }^{1} \mathrm{H} \mathrm{NMR}\left(\mathrm{CDCl}_{3}\right): \delta_{\mathrm{H}} 7.07-7.10\left(2 \mathrm{H}_{\text {arom. }}, \mathrm{dd}, J=3.6\right.$ $\mathrm{Hz}, J=5.2 \mathrm{~Hz}, 2 \mathrm{CH}$, thiophene), 7.29-7.32 (4 $\mathrm{H}_{\text {arom. }} \mathrm{m}, 4 \mathrm{CH}$, thiophene), 7.47-7.50 (4 $\mathrm{H}_{\text {arom. }} \mathrm{m}$, $4 \mathrm{CH}$, thianthrene), $7.73\left(2 \mathrm{H}_{\text {arom. }}, \mathrm{s}, 2 \mathrm{CH}\right.$, thianthrene). ${ }^{13} \mathrm{C} \mathrm{NMR}\left(\mathrm{CDCl}_{3}\right): \delta_{\mathrm{C}} 123.7,125.3$, 125.5, 125.9, 128.2, 129.0, 134.3, 134.4, 136.0, 142.7 (C-Ar). MS, $m / z(\%)=379.98$; Anal. Calcd for $\mathrm{C}_{20} \mathrm{H}_{12} \mathrm{~S}_{4}$ : C, 63.12; H, 3.18; S, 33.70\%, Found: C, 63.08; H, 3.11; S, 33.68\%

2,8-Bis[2-(3,4-ethylenedioxythiophene)] thianthrene (10). Substantially the same procedure as for synthesis of 2,8-bis(2-thiophene)thianthrene was repeated using $1.5 \mathrm{~g}$ (4.01 mmol) dibromothianthrene, $3.80 \mathrm{~g}(8.82 \mathrm{mmol})$ 2-(tributylstannyl)ethylenedioxythiophene, $0.74 \mathrm{~g}(0.64$ $\mathrm{mmol}$ ) tetrakis(triphenylphosphine)palladium(0). The desired product was obtained by column chromatography with hexane:ethyl acetate $(3: 1 ; \mathrm{V}: \mathrm{V})$ as an eluent. Green solid was synthesized with $54 \%$ yield $(1.01 \mathrm{~g}), \mathrm{mp} 116^{\circ} \mathrm{C} .{ }^{1} \mathrm{H} \mathrm{NMR}\left(\mathrm{CDCl}_{3}\right): \delta_{\mathrm{H}} 4.21-4.31\left(8 \mathrm{H}, \mathrm{m}, 2 \mathrm{O}-\mathrm{CH}_{2}-\mathrm{CH}_{2}-\mathrm{O}\right.$, 
ethylenedioxythiophene), 6.31 (2 $\mathrm{H}_{\text {arom. }}, \mathrm{s}, \quad 2 \mathrm{~S}-\mathrm{CH}-\mathrm{C}$, ethylenedioxythiophene), 7.40-7.44 $\left(2 \mathrm{H}_{\text {arom. }}, \mathrm{dd}, J=4.1 \mathrm{~Hz}, J=8.2 \mathrm{~Hz}, 2 \mathrm{CH}\right.$, thianthrene), 7.54-7.57 $\left(2 \mathrm{H}_{\text {arom. }}\right.$, dd, $J=1.9 \mathrm{~Hz}, J=8.2 \mathrm{~Hz}$, $2 \mathrm{CH}$, thianthrene), 7.87-7.89 (2 $\mathrm{H}_{\text {arom. }}$. $\mathrm{dd}, J=1.9 \mathrm{~Hz}, \mathrm{~J}=4.4 \mathrm{~Hz}, 2 \mathrm{CH}$, thianthrene). ${ }^{13} \mathrm{C}$ NMR $\left(\mathrm{CDCl}_{3}\right): \delta_{\mathrm{C}} 64.4\left(2 \mathrm{O}-\mathrm{CH}_{2}\right.$, ethylenedioxythiophene), $64.8\left(2 \mathrm{O}-\mathrm{CH}_{2}\right.$, ethylenedioxythiophene), 98.3 (2S-CH, ethylenedioxythiophene), 115.9 (2S-C(C)2, ethylenedioxythiophene), 125.0, 125.7, 128.6, 133.0, 133.1, 135.7, 138.8, 142.3 (C-Ar). MS, $m / z(\%)=495.99$; Anal. Calcd for $\mathrm{C}_{24} \mathrm{H}_{16} \mathrm{O}_{4} \mathrm{~S}_{4}: \mathrm{C}, 58.04 ; \mathrm{H}, 3.25 ; \mathrm{O}, 12.89 ; \mathrm{S}, 25.82 \%$, Found: C, 58.00; H, 3.20; S, 25.79\%

2,8-Bis(2-oxazoyl)thianthrene (11). Creamish oil, yield 61\% (0.62 g). ${ }^{1} \mathrm{H} \mathrm{NMR}\left(\mathrm{CDCl}_{3}\right): \delta_{\mathrm{H}}$ $7.26\left(2 \mathrm{H}_{\text {arom. }}, \mathrm{d}, J=3.4 \mathrm{~Hz}, 2 \mathrm{CH}\right.$, oxazole $), 7.54-7.58\left(2 \mathrm{H}_{\text {arom. }}\right.$, dd, $J=4.9 \mathrm{~Hz}, J=8.2 \mathrm{~Hz}, 2 \mathrm{CH}$, thianthrene), $7.73\left(2 \mathrm{H}_{\text {arom. }}, \mathrm{s}, 2 \mathrm{CH}\right.$, thianthrene $), 7.91-7.95\left(2 \mathrm{H}_{\text {arom. }}\right.$, dd, $J=1.8 \mathrm{~Hz}, J=8.2 \mathrm{~Hz}$, $2 \mathrm{CH}$, thianthrene), 8.16-8.18 $\left(2 \mathrm{H}_{\text {arom. }}, \mathrm{d}, J=1.8 \mathrm{~Hz}, J=3.2 \mathrm{~Hz}, 2 \mathrm{CH}\right.$, oxazole $) .{ }^{13} \mathrm{C} \mathrm{NMR}\left(\mathrm{CDCl}_{3}\right)$ : $\delta_{\mathrm{C}} 124.8,125.2,125.5,126.3,127.5,128.8,135.4,136.3,160.1(\mathrm{C}-\mathrm{Ar}) . \mathrm{MS}, \mathrm{m} / z(\%)=350.42$; Anal. Calcd for $\mathrm{C}_{18} \mathrm{H}_{10} \mathrm{~N}_{2} \mathrm{O}_{2} \mathrm{~S}_{2}$ : C, 61.70; H, 2.88; N, 7.99; O, 9.13; S, 18.30\%, Found: C, 61.66; H, 2.85; N, 7.86; S, 18.25\%

2,8-Bis(2-furanyl)thianthrene (12). Pale yellow-green solid, 74\% (0.69 g), mp 204-206 ${ }^{\circ} \mathrm{C} .{ }^{1} \mathrm{H}$ $\operatorname{NMR}\left(\mathrm{CDCl}_{3}\right): \delta_{\mathrm{H}} 7.07-7.10\left(2 \mathrm{H}_{\text {arom. }}\right.$, $\mathrm{dd}, J=3.7 \mathrm{~Hz}, J=5.1 \mathrm{~Hz}, 2 \mathrm{CH}$, furan $), 7.30-7.32\left(4 \mathrm{H}_{\text {arom. }}\right.$, $\mathrm{m}, 4 \mathrm{CH}$, furan), 7.48-7.51 (4 $\mathrm{H}_{\text {arom. }} \mathrm{m}, 4 \mathrm{CH}$, thianthrene), $7.74\left(2 \mathrm{H}_{\text {arom. }}, \mathrm{s}, 2 \mathrm{CH}\right.$, thianthrene $) .{ }^{13} \mathrm{C}$ NMR $\left(\mathrm{CDCl}_{3}\right): \delta_{\mathrm{C}} 123.7,125.3,125.5,126.0,128.2,129.0,134.3,134.4,136.0,142.7$ (C-Ar). MS, $m / z(\%)=371.02\left(\mathrm{M}+\mathrm{Na}^{+}\right)$; Anal. Calcd for $\mathrm{C}_{20} \mathrm{H}_{12} \mathrm{O}_{2} \mathrm{~S}_{2}$ : C, 68.94; H, 3.47; O, 9.18; S, $18.40 \%$, Found: C, $68.89 ; \mathrm{H}, 3.42 ; \mathrm{S}, 18.35 \%$

2,8-Bis(2-pyridyl)thianthrene (13). Using $1.0 \mathrm{~g}(2.67 \mathrm{mmol})$ dibromothianthrene, $2.2 \mathrm{~g}$ (5.98 mmol) 2-(tributylstannyl)pyridine, $0.4 \mathrm{~g}(0.35 \mathrm{mmol})$ tetrakis(triphenylphosphine)palladium $(0)$, compound 2,8-bis(2-pyridyl)thianthrene was obtained as yellow crystals according to substantially the same procedure as for 2,8-bis(2-furanyl)thianthrene. The crude product was purified by silica gel column chromatography (eluent - hexane:ethyl acetate $(8: 1 ; \mathrm{V}: \mathrm{V})$ ). Product was synthesized with yield $61 \%(0.62 \mathrm{~g}), \mathrm{mp} 113-114^{\circ} \mathrm{C} .{ }^{1} \mathrm{H}$ NMR $\left(\mathrm{CDCl}_{3}\right): \delta_{\mathrm{H}} 7.23-7.28$ ( $\left.2 \mathrm{H}_{\text {arom. }}, \mathrm{m}, 2 \mathrm{CH}\right), 7.58\left(2 \mathrm{H}_{\text {arom. }}, \mathrm{d}, J=8.1 \mathrm{~Hz}, 2 \mathrm{CH}\right), 7.70-7.79\left(4 \mathrm{H}_{\text {arom. }}, \mathrm{m}, 4 \mathrm{CH}\right), 7.87-7.91$ $\left(2 \mathrm{H}_{\text {arom. }}, \mathrm{dd}, J=2.0 \mathrm{~Hz}, J=8.1 \mathrm{~Hz}, 2 \mathrm{CH}\right), 8.16\left(2 \mathrm{H}_{\text {arom. }}, \mathrm{d}, J=2.0 \mathrm{~Hz}, 2 \mathrm{CH}\right), 8.69\left(2 \mathrm{H}_{\text {arom. }}, \mathrm{d}, J=5.0\right.$ $\mathrm{Hz}, 2 \mathrm{CH}) .{ }^{13} \mathrm{C} \mathrm{NMR}\left(\mathrm{CDCl}_{3}\right): \delta_{\mathrm{C}} 120.4,122.6,126.2,127.0,128.8,128.9,136.0,136.9,139.2$, 149.8, 155.8 (C-Ar). MS, $m / z(\%)=371.07\left(\mathrm{M}^{+}\right)$; Anal. Calcd for $\mathrm{C}_{22} \mathrm{H}_{14} \mathrm{~N}_{2} \mathrm{~S}_{2}$ : C, 71.32; H, 3.81; N, 7.56; S, 17.31\%, Found: C, 71.28; H, 3.77; N, 7.54; S, 17.28\%

\section{Electrochemical measurement}

The solutions of the synthesized compounds with the concentration of $1.0 \mathrm{mM}$ were used for cyclic voltamperometry measurements. Electrochemical studies were conducted in $0.1 \mathrm{M}$ solution of $\mathrm{Bu}_{4} \mathrm{NBF}_{4}$ (Sigma Aldrich 99\%) in anhydrous dichloromethane at room temperature. The electrochemical investigations were carried out using Eco Chemie Company's Autolab potentiostat "PGSTAT20". The results were collected using GPES (General Purpose Electrochemical System) software. The electrochemical cell comprised platinum wire with $1 \mathrm{~mm}$ diameter of working area as working electrode, $\mathrm{Ag} / \mathrm{AgCl}$ reference electrode and platinum coil 
as auxiliary electrode. Cyclovoltamperometric measurements were conducted at $50 \mathrm{mV} / \mathrm{s}$ potential rate.

\section{Acknowledgements}

The authors gratefully acknowledge the financial support of the Polish National Centre of Progress of Explorations Grant no. NR05-0017-10/2010 and Wroclaw University of Technology. The work was also co-financed by the European Union within the European Social Fund.

Authors are very grateful to Dr K. Ślepokura from University of Wroclaw, Department of Crystallography, for help in crystallographic studies of synthesized structure (X-Ray study).

\section{References}

1. Eichen, Y.; Nakhmanovich, G.; Goreli, V.; Epshtein, O.; Poplawski, J. M.; Ehrenfreund, E. J. Am. Chem. Soc 1998, 120, 10463.

2. Lu, W.; Fadeev, A. G.; Qi, B. H.; Smela, E.; Mattes, B. R.; Ding, J.; Spinks, G.M.; Mazurkiewicz, J.; Zhou, D. Z.; Wallace, G. G.; MacFarlane, D. R.; Forsyth, S. A.; Forsyth, M. Science 2002, 297, 983.

3. Yang, C. M.; Liao, H. H.; Hong, S. F.; Meng, H. F.; Tseng, S. R.; Hsu, C. S. Synth. Met. 2008, 158, 25.

4. Zhu, Y.; Gibbons, K. M.; Kulkarni, A. P.; Jenekhe, S. A. Macromolecules 2007, 40, 804.

5. Ritchie, J.; Ruseckas, A; Andre, P.; Munther, C.; Van Ryssen, M.; Vize, D. E.; Crayston, J. A.; Samuel, I. D. W. Synth. Met. 2009, 159, 583.

6. Kostler, S.; Rudorfel, A.; Haase, A.; Satzinger, V.; Jakopic, G.; Ribitsch, V. Advan. Mater. 2009, 21, 2505.

7. Lovell, J. M.; Beddoes, R. L.; Joule, J. A. Tetrahedron 1996, 52, 4745.

8. Tsai, E. W.; Throckmorton, L.; McKellar, R.; Baar, M.; Kluba, M.; Marynick, D. S.; Rajeshwar, K.; Temay, A. L. J. Electroanal. Chem. Interfacial Electrochem. 1986, $210,45$.

9. Ogawa, S.; Muraoka, H.; Sato, R. Tetrahedron Lett. 2006, 47, 2479.

10. Friedrich, R.; Janietz, S.; Wedel, A. Macromol. Chem. Phys. 1999, 200, 731.

11. Zhu, Y.; Babel, A.; Jenekhe, S. A. Macromol. 2005, 38, 7983.

12. Ding, J.; Day, M.; Robertson, G.; Roovers, J. Macromol. 2002, 35, 3474.

13. Sołoducho, J.; Idzik, K.; Cabaj, J.; Doskocz, J.; Łapkowski, M.; Plewa, S. Arkivoc 2007, (vi), 75 .

14. Gilman, H.; Swayampati, D. R. J. Am. Chem. Soc. 1955, 77, 5944.

15. Kaniskan, N.; Elmali, D.; Civcir, P. U. Arkivoc 2008, (xii), 17.

16. Kong, X. X.; Kulkarni, A. P.; Jenekhe, S. A. Macromol. 2003, 36, 8992.

17. Lovell, J. M.; Joule, J. A. J. Chem. Soc., Perkin Trans. 1996, 1, 2391. 